\title{
Dopaminergic neurotransmitter systems in Alzheimer's disease and in Down's syndrome at middle age
}

\author{
D M A MANN, P O YATES, B MARCYNIUK \\ From the Department of Pathology, University of Manchester, UK
}

SUMMARY In 15 patients with Alzheimer's disease and in 10 with Down's syndrome at middle age, there was severe atrophy, neurofibrillary degeneration and loss of pigmented dopaminergic nerve cells from ventral tegmental area (A10) whereas nerve cells in neighbouring substantia nigra (A9) were much less affected in all three respects. It is suggested that these findings may represent different patterns of damage within the two systems in these conditions which may relate to the presence of Alzheimer type changes (senile plaques) within their respective projection fields.

While an atrophy, neurofibrillary degeneration and loss of those nerve cells comprising the cortically projecting cholinergic, ${ }^{1-15}$ noradrenergic ${ }^{111416-21}$ and serotonergic ${ }^{1121-23}$ neurotransmitter systems is well established in Alzheimer's disease, less is definitely known concerning the dopaminergic systems based on the melanin pigmented neurons of the substantia nigra (SN), (A9) and ventral tegmental area (VTA), (A10). Biochemical studies ${ }^{24-27}$ indicate that dopamine and/or homovanillic acid (HVA) concentrations are not greatly altered within caudate nucleus and putamen, 24-27 though losses of both these substances have been recorded within frontal cortex and amygdala. ${ }^{25} 27$ These findings may represent different patterns of damage within SN and VTA nerve cell groups which have differing projection systems, the SN projecting mainly to basal ganglia via the nigroneostriatal tract and VTA to cerebral cortex (amygdala and frontal cortex) via mesolimbic and mesocortical pathways. In this study we have examined neurons of SN and VTA in Alzheimer's disease and in middle aged patients with Down's syndrome for Alzheimer type changes (neurofibrillary tangles)

Address for reprint requests: Dr DMA Mann, Department of Pathology, University of Manchester, Stopford Building, Oxford Rd, Manchester M139PT, UK.

Received 15 April 1986.

Accepted 23 May 1986 and we have also assessed the degree of damage to these systems in both conditions by counting the numbers of nerve cells and by measuring the volume of their nucleolus.

\section{Materials and methods}

Brains were obtained at necropsy from 15 moderately to severely demented patients of age range 53-89 years (mean $73.3 \pm 3 \cdot 1$ (SE) years) dying with histologically verified Alzheimer's disease, and from 10 middle aged patients with Down's syndrome (age range 51-65 years; mean 59.1 \pm 1.4 (SE) years) whose brains also showed numerous senile plaques and neurofibrillary tangles within cerebral cortex and hippocampus. From the formalin fixed brains, a standard block of mid brain was cut at the level of the red nucleus to include SN and VTA nerve cell groups, and from these blocks paraffin sections were cut at $5 \mu \mathrm{m}$ and $16 \mu \mathrm{m}$ thickness. Sections cut at $5 \mu \mathrm{m}$ were stained using conventional neuropathological techniques including a modified Palmgren method ${ }^{28}$ for neurofibrillary tangles, whereas those cut at $16 \mu \mathrm{m}$ were stained for RNA with Azure B. ${ }^{29}$ In these latter sections, the mean number of nucleolated nerve cells in SN and VTA on one side only per section were counted, using their neuromelanin as a natural marker ${ }^{30} 31$ and the mean volume of their nucleolus was also measured. ${ }^{1121}$ Overall mean values of cell counts and nucleolar volume were calculated for Alzheimer's disease and Down's syndrome groups and these were compared, using the $t$ test, with values from appropriate age-matched control patients (values drawn from a series of 67 mentally able patients of age range 10-97 years (see reference 21 for substantia nigra data; unpublished data for VTA)). 


\section{Results}

In both Alzheimer's disease and Down's syndrome, the SN was generally well preserved, with only an occasional cell undergoing degenerative depigmentation or showing neurofibrillary tangle formation (fig a and b). However, in VTA a variable picture of cell loss was seen and nerve cells containing neurofibrillary tangles were common in both Alzheimer's disease and Down's syndrome (fig $\mathrm{c}$ and

Table Mean ( \pm SEM) values of number (per section) and nucleolar volume of nerve cells of substantia nigra and ventral tegmental area in patients with Alzheimer's disease and Down's syndrome, with appropriate age-matched control values. Percentage loss in Alzheimer's disease and Down's syndrome (where significant) is given in parentheses

\begin{tabular}{|c|c|c|c|c|c|}
\hline \multirow[b]{2}{*}{ Patient group } & \multirow[b]{2}{*}{ Age (yr) } & \multicolumn{2}{|l|}{ Substantia nigra } & \multicolumn{2}{|c|}{ Ventral tegmental area } \\
\hline & & Cell number & Nucleolar volume & Cell number & Nucleolar volume \\
\hline $\begin{array}{l}\text { Alzheimer's disease }(\mathrm{n}=15) \\
\text { Control }(\mathrm{n}=10) \\
\text { Down's syndrome }(\mathrm{n}=10) \\
\text { Control }(\mathrm{n}=10) \\
\text { Alzheimer's disease }(\mathrm{n}=6)\end{array}$ & $\begin{array}{l}73 \cdot 3 \pm 3 \cdot 1 \\
74 \cdot 7 \pm 3 \cdot 0 \\
59 \cdot 1 \pm 1 \cdot 4 \\
60 \cdot 0 \pm 1 \cdot 5 \\
60 \cdot 7 \pm 2 \cdot 3\end{array}$ & $\begin{array}{l}409 \cdot 4^{*} \pm 28 \cdot 7(17 \cdot 3) \\
494.8 \pm 17 \cdot 8 \\
456.7 \pm 44.7 \\
548.3 \pm 15 \cdot 2 \\
461.8^{*} \pm 23.6(15 \cdot 8)\end{array}$ & $\begin{array}{l}39.7 \dagger \pm 2.2(18.8) \\
48.9 \pm 1 \cdot 7 \\
37 \cdot 3 \pm \pm 2 \cdot 0(27 \cdot 3) \\
51 \cdot 3 \pm 1 \cdot 6 \\
34 \cdot 6^{*} \pm 8 \cdot 5(30 \cdot 6)\end{array}$ & $\begin{array}{l}16 \cdot 4 \dagger \pm 2 \cdot 7(43 \cdot 1) \\
28 \cdot 8 \pm 2 \cdot 2 \\
14 \cdot 5 \pm \pm 2 \cdot 2(52 \cdot 6) \\
30 \cdot 6 \pm 1 \cdot 9 \\
12 \cdot 0 \dagger \pm 3 \cdot 7(60 \cdot 8)\end{array}$ & $\begin{array}{l}21 \cdot 9 \pm \pm 1 \cdot 7(35 \cdot 0) \\
33 \cdot 7 \pm 1 \cdot 4 \\
17 \cdot 7 \pm \pm 1 \cdot 6(50 \cdot 3) \\
35 \cdot 6 \pm 1 \cdot 3 \\
18 \cdot 5 \pm \pm 1 \cdot 5(48 \cdot 0)\end{array}$ \\
\hline
\end{tabular}

$*, \dagger, \ddagger$, denotes $\mathrm{p}<0.05,<0.01,<0.001$ versus controls, respectively.
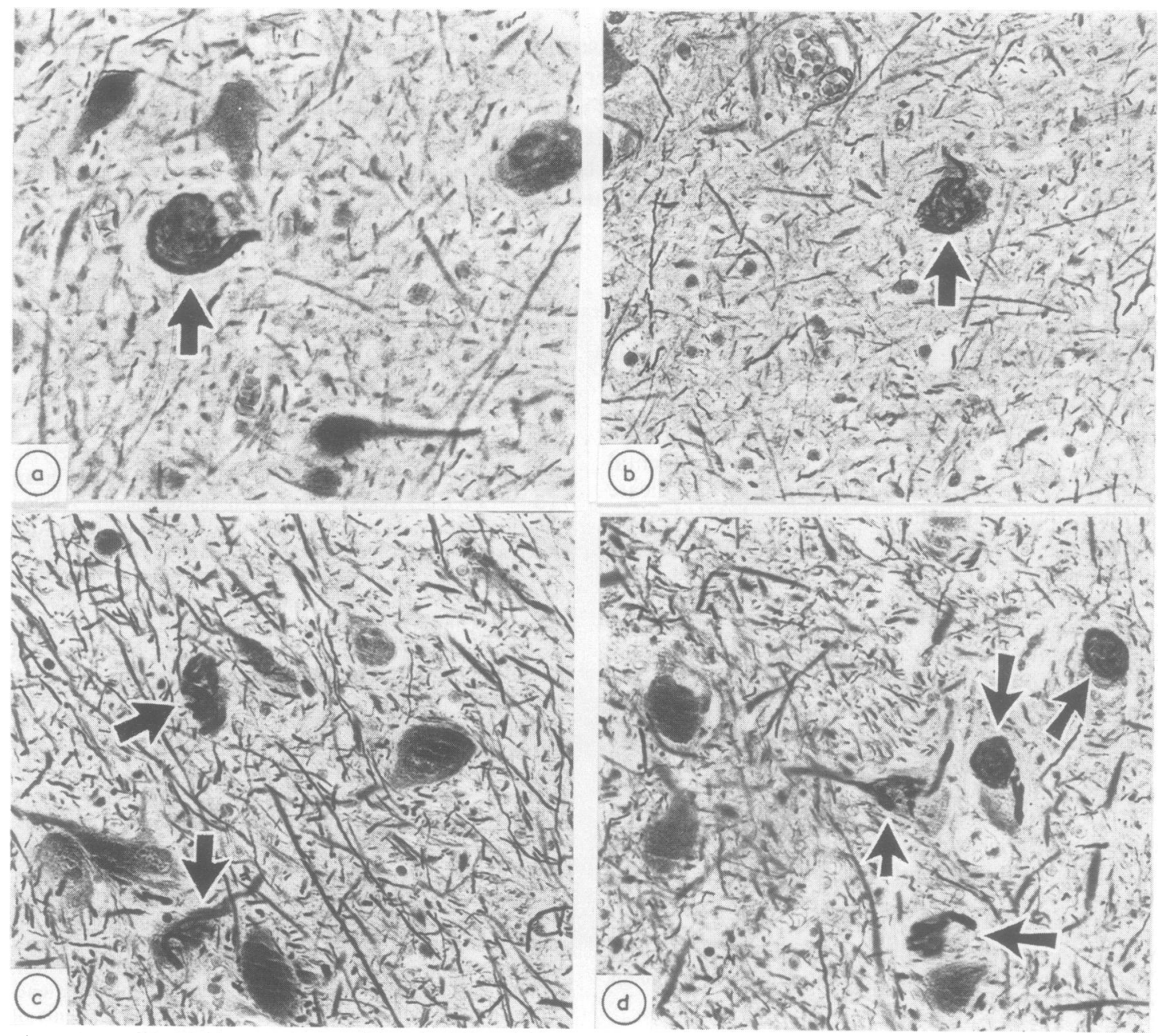

Fig Neurofibrillary tangles in nerve cells of substantia nigra ( $a$ and $b$ ) and ventral tegmental area ( $c$ and $d)$ in patients with Alzheimer's disease ( $a$ and $c$ ) and Down's syndrome at middle age ( $b$ and d). Palmgren $\times 540$. 
d). These changes were often more severe in Alzheimer's disease patients under 75 years of age.

Cell counting (table) showed that when compared with age-matched control patients, the number of surviving cells in SN was slightly lower $(15-17 \%)(p<$ 0.05 ) in Alzheimer's disease, but not significantly lower in Down's syndrome. The number of surviving cells in VTA, however, was significantly lower $(40-60 \%)(\mathrm{p}<0.01$ at least) in both patient groups (table). Nucleolar volume was reduced in cells of $\mathrm{SN}$, in both groups, by $18-30 \%$, whereas that in cells of VTA was decreased $(p<0.001)$ by more than $35 \%$ in both groups. No significant differences in either cell number or nucleolar volume were noted in either SN or VTA between the Down's syndrome and the six youngest Alzheimer's disease patients (which matched the Down's syndrome group for age) (table).

\section{Discussion}

Findings that the dopaminergic cells of the VTA (A10) are severely affected in Alzheimer's disease and Down's syndrome at middle age, whereas those of SN (A9) are much less damaged, has important pathogenetic implications. Neurons of VTA project to frontal and limbic areas of cortex whereas those of $\mathrm{SN}$ project to basal ganglia. It is difficult to conceive of a pathogenic event acting directly on dopaminergic cell bodies that would severely affect those of VTA, while sparing (relatively) those of SN. What seems more likely is that the primary damage to these neurons occurs within their terminal fields, with reduction in nucleolar volume (atrophy), neurofibrillary degeneration and loss of perikarya following as secondary retrograde changes. The observations that the pathological hallmarks of Alzheimer's disease (that is, plaques and tangles) are numerous in frontal and limbic areas, but scarce in basal ganglia, would be consistent with this argument.

There is evidence from other transmitter systems to support the concept that the subcortical damage of Alzheimer's disease and Down's syndrome is secondary to primary changes within cerebral cortex. For example, Perry and colleagues ${ }^{2}$ have shown that loss of cortical cholineacetyltransferase activity (CAT) far exceeds nerve cell loss within the parent nucleus basalis; indeed Pearson et $\mathbf{a l}^{\mathbf{3 2}}$ have identified patients with Alzheimer's disease who show loss of cortical CAT without decrease in cell number in nucleus basalis. The presence of CAT immunoreactivity within neurites of senile plaques ${ }^{33}$ implies that the senile plaque may be the site of the damage to nerve terminals, as do the quantitative relationships linking cell loss in different parts of nucleus basalis ${ }^{11-14}$ and locus caeruleus, ${ }^{1134}$ to plaque formation within their appropriate target fields in the cerebral cortex. Observation of tyrosinehydroxylase immunoreactivity within plaque neurites $^{35}$ suggests that the dopaminergic cells of VTA may also be damaged in a similar way to those of nucleus basalis and locus caeruleus. The much lesser degree of neurofibrillary degeneration, atrophy and loss of cells in SN, may relate either to the few plaques within basal ganglia, or it may arise from some degree of collateralisation (either "intended" or "aberrant") with the cerebral cortex.

This work was supported, in part, by a grant to one of us (BM) from the North Western Regional Health Authority. We thank Mrs P Bellinger for the preparation of the manuscript.

\section{References}

1 Whitehouse PJ, Price DL, Struble RG, Clarke AW, Coyle JT, De Long MR. Alzheimer's disease and senile dementia: Loss of neurones in the basal forebrain. Science 1981;215:1237-9.

2 Perry RH, Candy JM, Perry EK, et al. Extensive loss of choline acetyl transferase activity is not reflected by neuronal loss in the nucleus of Meynert in Alzheimer's disease. Neurosci Lett 1982;33:311-5.

3 Rossor MN, Svendsen C, Hunt SP, Mountjoy CQ, Roth $M$, Iversen LL. The substantia innominata in Alzheimer's disease: an histochemical and biochemical study of cholinergic marker enzymes. Neurosci Lett 1982;28:217-22.

4 Candy JM, Perry RH, Perry EK, et al. Pathological changes in the nucleus of Meynert in Alzheimer's and Parkinson's disease. J Neurol Sci 1983;59:277-89.

5 Nagai T, McGeer PL, Peng JH, McGeer EG, Dolman CE. Cholineacetyl transferase immunohistochemistry in brains of Alzheimer's disease patients and controls. Neurosci Lett 1983;36:195-9.

6 Wilcock GK, Esiri MM, Bowen DM, Smith CCT. The nucleus basalis in Alzheimer's disease: cell counts and cortical biochemistry. Neuropathol Appl Neurobiol 1983;9:175-9.

7 Tagliavini F, Pilleri G. Basal nucleus of Meynert. A neuropathological study in Alzheimer's disease, simple senile dementia, Pick's disease and Huntington's chorea. J Neurol Sci 1983;62:243-60.

8 Arendt T, Bigl V, Arendt A, Tennstedt A. Loss of neurones in the nucleus basalis of Meynert in Alzheimer's disease, paralysis agitans and Korsakoff's disease. Acta Neuropathol 1983;61:101-8.

9 Mann DMA, Yates PO, Marcyniuk B. Changes in nerve cells of the nucleus basalis of Meynert in Alzheimer's disease and their relationship to ageing and to the accumulation of lipofuscin pigment. Mech Ageing Dev 1984;25:189-204.

10 McGeer PL, McGeer EG, Suzuki J, Dolman CE, Nagai T. Aging, Alzheimer's disease and the cholinergic system of the basal forebrain. Neurology 1984;34: 741-5. 
11 Mann DMA, Yates PO, Marcyniuk B. Presenile Alzheimer's disease, senile dementia of Alzheimer type and Down's syndrome of middle age, all form an agerelated continuum of pathological changes. Neuropathol Appl Neurobiol 1984;10:187-205.

12 Arendt T, Bigl V, Tennstedt A, Arendt A. Correlation between cortical plaque count and neuronal loss in nucleus basalis in Alzheimer's disease. Neurosci Lett 1984;48:81-5.

13 Arendt T, Bigl V, Tennstedt A, Arendt A. Neuronal loss in different parts of the nucleus basalis is related to neuritic plaque formation in cortical target areas in Alzheimer's disease. Neuroscience 1985;14:1-14.

14 Mann DMA, Yates PO, Marcyniuk B. Correlation between senile plaque and neurofibrillary tangle counts in cerebral cortex and neuronal counts in cortex and subcortical structures in Alzheimer's disease. Neurosci Lett 1985;56:51-5.

15 Rogers JD, Brogan D, Mirra SS. The nucleus basalis of Meynert in neurological disease: a quantitative morphological study. Ann Neurol 1985;17:163-70.

16 Tomlinson BE, Irving D, Blessed G. Cell loss in the locus caeruleus in senile dementia of Alzheimer type. $J$ Neurol Sci 1981;49:419-28.

17 Mann DMA, Yates PO, Hawkes J. The noradrenergic system in Alzheimer and multi-infarct dementias. $J$ Neurol Neurosurg Psychiatry 1982;45:113-9.

18 Bondareff W, Mountjoy CQ, Roth M. Loss of neurones of adrenergic projection to cerebral cortex (nucleus locus caeruleus) in senile dementia. Neurology 1982; 32:164-9.

19 Mann DMA, Yates PO, Hawkes J. The pathology of the human locus caeruleus. Clin Neuropathol 1983;2:1-7.

20 Iversen LL, Rossor MN, Reynolds GP, et al. Loss of pigmented dopamine- $\beta$-hydroxylase positive cells from locus caeruleus in senile dementia of Alzheimer type. Neurosci Lett 1983;39:95-100.

21 Mann DMA, Yates PO, Marcyniuk B. Monoaminergic neurotransmitter systems in Alzheimer's presenile dementia and in senile dementia of Alzheimer type. Clin Neuropathol 1984;4:199-205.

22 Curcio CA, Kemper T. Nucleus raphe dorsalis in dementia of Alzheimer type: neurofibrillary changes and neuronal packing density. J Neuropathol Exp
Neurol 1984;43:359-68.

23 Yamamoto T, Hirano A. Nucleus raphe dorsalis in Alzheimer's disease: neurofibrillary tangles and loss of large neurones. Ann Neurol 1985;17:573-7.

24 Yates CM, Allison Y, Simpson J, Maloney AFJ, Gordon A. Dopamine in Alzheimer's disease and senile dementia. Lancet 1979;ii:851-2.

25 Adolfsson R, Gottfries CG, Roos BE, Winblad B. Changes in the brain catecholamines in patients with dementia of Alzheimer type. Br J Psychiatry 1979; 135:216-23.

26 Cross AJ, Crow TJ, Johnson JA, et al. Monoamine metabolism in senile dementia of Alzheimer type. $J$ Neurol Sci 1983;60:383-92.

27 Arai H, Kosaka K, lizuka R. Changes of biogenic amines and their metabolism in post mortem brains from patients with Alzheimer type dementia. $J$ Neurochem 1984;43:388-93.

28 Cross RB. Demonstration of neurofibrillary tangles in paraffin sections-a quick and simple method using Palmgren's technique. Med Lab Sci 1982;39:67-9.

29 Shea JR. A method for the in situ estimation of absolute amount of RNA using Azure B. J Histochem Cytochem 1970;18:143-52.

30 Bogerts B. A brainstem atlas of the catecholaminergic neurons in man using melanin as a natural marker. $J$ Comp Neurol 1981;197:63-80.

31 Saper CP, Petito CK. Correspondence of melaninpigmented neurones in human brain with Al-A14 catecholaminergic cell groups. Brain 1982;105:87-101.

32 Pearson RCA, Sofroniew MV, Cuello AC, et al. Persistence of cholinergic neurones in the basal nucleus of a brain with SDAT demonstrated by immunohistochemical staining for choline acetyl transferase. Brain Res 1983;289:375-9.

33 Kitt CA, Price DL, Struble RG, et al. Evidence for cholinergic neurites in senile plaques. Science 1984;226: 1443-5.

34 Marcyniuk B, Mann DMA, Yates PO. Loss of nerve cells from locus caeruleus in Alzheimer's disease is topographically arranged. Neurosci Lett 1986; 64:247-52.

35 Kitt CA, Struble RG, Cork LC, et al. Catecholaminergic neurites in senile plaques in prefrontal cortex of aged non-human primates. Neuroscience 1985;16:691-9. 